on a portion of a paper disk : a contiguous portion of the disk is illuminated by the pentane candle fixed on one side of the opening in the shutter. The disk can be moved on a trolley to and fro until equality of illumination is reached, when its distance from the candle is measured. This measure and the known distance of the observatory from the lighthouse give the necessary data for determining the illuminating power of the light. By these measurements, taken at different distances in various states of the atmosphere, the penetrative power of the several illuminants will be determined. For instance, in very clear weather the electric light may give twenty times the light of the oil light; a slight haze comes on and the electric light is found to be only ten times as bright. It has suffered in a greater ratio than the other. A mist blows by the towers, and the superiority of the electric light becomes less and less marked: before the lights are finally obscured the superiority has vanished. It need hardly be stated that this question of penetration is the most important point the Trinity House are called on to settle.

The principle of superposition of lights also raises an interesting point. When two lights are placed close together they can be seen at a greater distance than one light. Up to what point will this increase of range continue on multiplying the lights--without altering the intrinsic brightness of each? It may be that in thick weather the eye can detect a large area of low illumination better than a smaller area of higher illumination; and it may be that the electric light with its smaller lenses suffers from this reason in comparison with the oil and gas lights with their larger lenses.

We hope that the experiments will not be discontinued before these points have been thoroughly sifted, as they only can be satisfactorily, on the actual working scale.

We may add that the electric machines and cables are being tested by Prof. Grylls Adams, and the photometric observations taken by Mr. Harold Dixon. Mr. Vernon Harcourt is appointed to watch the experiments generally and report to the Board of Trade.

We give a plan of the district showing the point of observation, which includes the coast-guard stations and light-ships in the vicinity.

\section{THE INTERNATIONAL CONFERENCE ON EDUCATION}

THE Conference which was held at the Health Exhibition last week has achieved a remarkable success. It was attended by upwards of a thousand persons, including many of the leading teachers in English, Scotch, and continental schools, University professors, statesmen, managers of schools, and others interested in different ways in the subject of education. The interest was so well sustained that all four sections were more crowded on the last day than the first, and very general regret was expressed that the Conference should close so soon. Two circumstances mainly contributed to this result. The president, Lord Reay, by his tact and courtesy, his knowledge of foreign languages, and his cosmopolitan experience was singularly qualified, both to obtain from different continental States their most fitting representatives, and to give to these representatives when they arrived appropriate tasks and a worthy welcome. And Lord Reay was helped in the task of organising the Conference by a small but efficient committee, by whom during several previous months the work of selecting the readers of papers had been sedulously pursued. Unless pains had been taken in relation to each subject of discussion to secure that it should be initiated by a person who spoke upon it with some authority, and special knowledge, the result would have been far less satisfactory.

The Conference sat in four sections, which were at work simultaneously during five days. The first of these was devoted mainly to the consideration of questions relating to elementary education. The best and most fruitful subjects of discussion here were the Kindergarten, physical training, and the right way of inspecting, examining, or otherwise testing the work of pupils. Fröbel's principles, which have done so much to transform the system of training very young children in England, in Belgium, and in France, were expounded with much fulness of knowledge and felicity of illustration by some of Fröbel's own countrymen and disciples, as well as by ladies who have in England qualified themselves by special sympathy and knowledge to become his exponents. Closely akin to this subject were the topics of gymnastic and physical training, the better construction of schools and school apparatus, and the indirect effect of pictorial or other decorations in improving the taste and cultivating the imagination, and of increasing the scholars' interest in their work. The Swedish and other systems of bodily exercise, and the means of sense training by music and by object lessons were well discussed. On the general subject of the organisation of elementary education, which was debated in a crowded audience under the presidency of the Vice-President of the Council, the results were somewhat disappointing. Some of the teachers took the opportunity of the presence of their official chief to urge the demand with which the public have been long familiar, for grants of public money on easier conditions, and for the abandonment of the prin ciple of payment by results. But no other practical method of distributing the public money was suggested, and it was generally felt that the Vice-President had an easy victory over those who sought to attack the principles of the recently-modified Code. A more important subject was raised in the animated debate on the inspection and examination of schools, which was rendered more apposite at the moment by the appearance of the recommendations of the Select Committee of the House of Commons, recommending that there should be in England a Minister of Public Instruction, and that he should have inter alia the duty of inspecting and annually reporting on the endowed secondary schools. It was perceived that this was a step of considerable moment and significance. Under the Act of 1869 endowed schools have been re-organised, and their governing bodies and schemes of study re-constituted. But neither the Commissioners who administer that Act, nor the public, know anything of the way in which those schemes are carried out, nor of the actual performances of the schools from year to year. There was among the larger number of earnest speakers on this point, a very general agreement on two points: first that some such public supervision over the reformed foundations was absolutely necessary, in order to keep them efficient; and secondly, that as there would be in this case no grant to administer, there would not be, as in elementary schools, any need to formulate conditions as to instruction, but simply to inquire in every case what the endowed school professed to do, and to see how far it had realised its own ideal. It is rather for the purpose of knowing what the schools are doing, than for that of imposing upon them by athority any theory or official ideal that State supervision seems to be demanded in regard to endowed schools.

In the second of the sections the principal topics of discussion were connected with scientific, technical, and artistic instruction. The fact that the Conference held its sittings in the new and beautiful buildings recently erected for the City and Guilds of London Technical Institute, naturally excited special interest, and awakencd discussion as to the place which the physical sciences ought to hold in general education, as well as the special uses to which the Institute might be put in connection with the improvement of handicrafts and skilled trade. Mr. Magnus, Prof. Armstrong, Mr. Sparkes, and other 
authorities whose names are associated with the improved teaching of science or of art in this country, were enabled to compare notes with professors of similar subjects from France and the United States, and some useful results were arrived at. In one special department of this Section, the agriculturists, under the presidency of Lord Fortescue and Sir Thomas Acland, held several long and animated discussions on the better teaching of agricultural science, on farm schools, and on the right education of boys intended to be farmers. In another department the subject of school museums was brought forward in an interesting paper by Dr. Jex-Blake of Rugby, and divers subsidiary aids to school instruction, such as field excursions, organised visits to factories, museums, and other places of interest, were suggested or described. Some of the more skilled and earnest of the elementary teachers, who, by their own personal influence, have secured the co-operation of their scholars in the formation of school museums illustrative of the flora, fauna, history, or industry of particular districts, gave interesting accounts of their plans and of the practical results which attended them; and from France and Belgium, and particularly from Liverpool, remarkable testimony was produced as to the success which had attended school savings' banks, and the influence they had exercised on the children and their parents.

The third section was mainly concerned with Universities and their relation to secondary instruction on the one hand, and to the liberal professions on the other. Profs. Morley, Fleeming Jenkin, and Seeley discoursed severally on those parts of the University curriculum with which their own names are most prominently associated, while the legal and theological aspects of the University question were discussed by Sir C. Bowen and Prof. Lorimer, by Cardinal Manning and Dr. Wace. The chief interest of this section, however, lay in that department in which the proper relation between the teaching and the examining functions of a University were examined by Sir George Young and others. The status of the present University of London was regarded by many speakers as unsatisfactory, notwithstanding the searching and effective character of its examinations, and the stimulating influence which its regulations have had upon the education of students in all parts of the country. A strong wish was expressed by many speakers, that the greatest city in the world should possess a teaching University, rather than a mere examining Board; and that some means should be found of co-ordinating all the higher agencies now at work in the metropolis in such a way as to constitute a London University of a new and nobler type. The duties of the Universities to our Indian Empire were well urged upon the Conference by Prof. Monier Williams; and the whole subject of the relations of the Universities to the education of women was debated in a crowded room and with great animation and interest, apropos of a paper by Mrs. Henry Sidgwick, whose own valuable services at Newnham have given her a special claim to speak with authority on such a topic.

The fourth section had a somewhat miscellaneous programme, but may be briefly described as concerned with problems connected with secondary and intermediate education. The first of these problems was the training of teachers, and the best means of securing for secondary schools a supply of teachers, qualified in respect to their knowledge of the theory and practice of their art, not less satisfactorily than the trained and certificated teachers of the elementary schools are, relatively to the humbler work which they have to do. Mr. Quick, Mr. Storr, Professors Laurie and Meiklejohn, and others who have made this a special subject of investigation, were enabled to throw much light on the recent efforts of the Universities to provide instruction in the art and philosophy of teaching, and to give professional certificates to persons qualified to receive them. It was manifest, however, from this discussion, that the one great hindrance in the way of such progress was the practical disbelief among the head-masters in the value of special professional training. Were it once understood that over and above the possession of a good University degree a head-master in search of an assistant would require, or would even cateris paribus prefer that the candidate should show a knowledge of the principles of teaching or the literature of his profession, the arrangements of the Universities for imparting such knowledge would soon produce good fruit. At present, however, the teacher's diplomas issued by the Universities of Cambridge and London appear to possess but little market value in the public schools. It was shown, however, that in girls' schools of the highest class the work of professional training was much more keenly appreciated; and that among the foremost women engaged in the teaching profession, the strongest interest had been taken not only in the proposals of the Universities, but also in the Bishopsgate Training College, the Lectures of the College of Preceptors, and other public measures for ensuring specific instruction in the art and mystery of their craft for the skilled teachers of the future. Une of the warmest, and at the same time one of the ablest debates in the Conference concerned the possible future relations of the State to secondary and higher education. Mr. Lyulph Stanley contended strongly for some public provision for the establishment of good secondary schools where they are deficient, and sketched out a plan which had evidently been thought out with some care, for the creation of such schools by means of rates, and for the supervision of such schools by local bodies having the public confidence. Canon Daniel, on the other hand, contended with much ability in favour of absolute freedom for local and religious bodies in the matter of secondary instruction, and against any attempt on the part of the State to initiate or control it. He pointed out, with considerable force, the remarkable success of the Girls' Public Day Schools Company, and remarked on the rapid growth of other agencies of a similar kind for supplying good middle-class schools, and for adapting the supply to the religious, social, and educational wants of different classes of the community.

Perhaps, on the whole, the most striking feature of the Conference, in the eyes of the numerous foreigners who were present and took part in the proceedings, was the remarkable interest evinced in the improved education of women; the variety of new fields now opening to their intelligence, activity, and public usefulness, and the number of ladies who took an active and effective share in the various discussions. Another point of special interest was the international character of the whole Conference, and the warm welcome with which the experience of experts from France, Belgium, Switzerland, Germany, and the United States, was received in all the sections. There has probably never been in the history of education in this country a gathering which afforded such an excellent opportunity for the interchange of opinions and suggestions between English and foreign teachers. And the executive of the Exhibition may well be congratulated on having added to their other successes the completion of a work of pre-eminent and far-reaching usefulness-a Conference which, for the ability of those who took part in it, for the high tone and courtesy of its discussions, and for the fruitfulness of its practical suggestions, has left an enduring and most pleasing impression on all who took part in it.

Among the subsidiary features of the Conference not the least useful were the visits organised by the Committee to some of the more characteristic and important of English schools. The most successful of these visits was that paid to the new buildings of St. Paul's School at West Kensington, which, though not yet occupied by the scholars, is now nearly complete in all its appointments. The party, nearly fifty in number, consisted largely of 
foreign teachers from various countries. They were conducted over Mr. Waterhouse's costly and beautiful building by the Clerk of the Works and by a member of the governing body, and evinced much interest in observing all the latest improvements in school construction and fittings, and in inspecting the library, laboratories, lecture-rooms, and the ample appliances for physical training.

It is understood that the results of the Conference, the text of the papers, and a summary of the discussions will shortly appear in four or five volumes.

\section{THE VOYAGE OF THE "VETTOR PISANI"}

K NOWING how much NATURE is read by all the I naturalists of the world, I send these few lines, which I hope will be of some interest.

The Italian R.N. corvette Vettor Pisani left Italy in April 1882 for a voyage round the world with the ordinary commission of a man-of-war. The Minister of Marine, wishing to obtain scientific results, gave orders to form, when possible, a marine zoological collection, and to carry on surveying, deep-sea soundings, and abyssal thermometrical measurements. The officers of the ship received their different scientific charges, and Prof. Dohrn, director of the Zoological Station at Naples, gave to the writer the necessary instructions for collecting and preserving sea animals.

At the end of 1882 the Vettor Pisani visited the Straits of Magellan, the Patagonian Channels, and Chonos and Chiloe Islands; we surveyed the Darwin Channel, and following Dr. Cuningham's work (who visited these places on board H.M.S. Nassau), we made a numerous collection of sea animals by dredging and fishing along the coasts.

While fishing for a big shark in the Gulf of Panama during the stay of our ship in Taboga Island one day in February, with a dead calm, we saw several great sharks some miles from our anchorage. In a short time several boats with natives went to sea, accompanied by two of the Vettor Pisani's boats.

Having wounded one of these animals in the lateral part of the belly, we held him with lines fixed to the spears; he then began to describe a very narrow curve, and irritated by the cries of the people that were in the boats, ran off with a moderate velocity. To the first boat, which held the lines just mentioned, the other boats were fastened, and it was a rather strange emotion to feel ourselves towed by the monster for more than three hours with a velocity that proved to be two miles per hour. One of the boats was filled with water. At last the animal was tired by the great loss of blood, and the boats assembled to haul in the lines and tow the shark on shore.

With much difficulty the nine boats towed the animal alongside the Vettor Pisani to have him hoisted on board, but it was impossible on account of his colossal dimensions. But, as it was high water we went towards a sand beach with the animal, and we had him safely stranded at night.

With much care were inspected the mouth, the nostrils, the ears, and all the body, but no parasite was found The eyes were taken out and prepared for histological study. The set of teeth was all covered by a membrane that surrounded internally the lips; the teeth are very little and almost in a rudimental state. The mouth, instead of opening in the inferior part of the head, as in common sharks, was at the extremity of the head; the jaws having the same bend.

Cutting the animal on one side of the backbone we met (I) a compact layer of white fat 20 centimetres deep; (2) the cartilaginous ribs covered with blood vessels; (3) a stratum of flabby, stringy, white muscle, 60 centi- metres high, apparently in adipose degeneracy; (4) the stomach.

By each side of the backbone he had three chamferings, or flutings, that were distinguished by inflected interstices. The colour of the back was brown with yellow spots that became close and small towards the head so as to be like marble spots. The length of the shark was $8.90 \mathrm{~m}$. from the mouth to the pinna caudalis extremity, the greatest circumference $6.50 \mathrm{~m}$., and $2.50 \mathrm{~m}$. the main diameter (the outline of the two projections is made for giving other dimensions).

The natives call the species Tintoreva, and the most aged of the village had only once before fished such an animal, but smaller. While the animal was on board we saw several Remora about a foot long drop from his mouth; it was proved that these fish lived fixed to the palate, and one of them was pulled off and kept in the zoological collection of the ship.

The Vettor Pisani has up to the present visited Gibraltar, Cape Verde Islands, Pernambuco, Rio Janeiro, Monte Video, Valparaiso, many ports of Peru, Guayaquil, Panama, Galapagos Islands, and all the collections were up to this sent to the Zoological Station at Naples to be studied by the naturalists. By this time the ship left Callao for Honolulu, Manila, Hong Kong, and, as the Challenger had not crossed the Pacific Ocean in these directions, we made several soundings and deep-sea thermometrical measurements from Callao to Honolulu. Soundings are made with a steel wire (Thomson system) and a sounding-rod invented by J. Palumbo, captain of the ship. The thermometer employed is a Negretti and Zambra deep-sea thermometer, improved by Captain Maguaghi (director of the Italian R.N. Hydrographic Office).

With the thermometer wire has always been sent down a tow-net which opens and closes automatically, also invented by Captain Palumbo. This tow-net has brought up some little animals that I think are unknown.

Honolulu, July I

G. Chierchia

The shark captured by the Vettor Pisani in the Gulf of Panama is Rhinodon typicus, probably the most gigantic fish in existence. Mr. Swinburne Ward, formerly Commissioner of the Seychelles, has informed me that it attains to a length of 50 feet or more, which statement was afterwards confirmed by Prof. E. P. Wright. Originally described by Sir A. Smith from a single specimen which was killed in the neighbourhood of Cape Town, this species proved to be of not uncommon occurrence in the Seychelle Archipelago, where it is known by the name of "Chagrin." Quite recently Mr. Haly reported the capture of a specimen on the coast of Ceylon. Like other large sharks (Carcharodon rondeletii, Selache maxima, \&c.), Rhinodon has a wide geographical range, and the fact of its occurrence on the Pacific Coast of America, previously indicated by two sources, appears now to be fully established. ' $T$. Gill' in 1865 described a large shark known in the Gulf of California by the name of "Tiburon ballenas" or whale-shark, as a distinct genus-Micristodus punctatus-which, in my opinion, is the same fish. And finally, Prof. W. Nation examined in 1878 a specimen captured at Callao. Of this specimen we possess in the British Museum a portion of the dental plate. The teeth differ in no respect from those of a Seychelles Chagrin; they are conical, sharply pointed, recurved, with the base of attachment swollen. Making no more than due allowance for such variations in the descriptions by different observers, as are unavoidable in accounts of huge creatures examined by some in a fresh, by others in a preserved state, we find the principal characteristics identical in all these accounts, viz. the form of the body, head, and snout, relative measurements, position of mouth, nostrils and eyes, dentition, peculiar ridges on the side of the trunk and tail, coloration, \&c. I have only to add that this 